\title{
ANALISIS DETERMINAN KEJADIAN PENYAKIT MALARIA DI KECAMATAN KUTAMBARU TAHUN 2017
}

\author{
Rahmadani Sitepu ${ }^{1}$, Alamsyah Lukito $^{1}$, Elaninanivi ${ }^{2}$ \\ ${ }^{1}$ Fakultas Kedokteran, Universitas Islam Sumatera Utara \\ ${ }^{2}$ Magister Fakultas Kesehatan Masyarakat, Universitas Sumatera Utara
}

\begin{abstract}
ABSTRAK
Malaria adalah penyakit yang menyerang manusia, burung, kera dan primata lainnya, hewan melata dan hewan pengerat yang disebabkan oleh infeksi protozoa dari genus plasmodium. Kejadian atau penularan penyakit menular ditentukan oleh faktorfaktor risiko/determinan yang disebut host, agent, dan environment. Dalam penelitian akan menggunakan penelitian analitik dengan desain case control, Penelitian ini bersifat retrospektif yaitu rancang bangun dengan melihat kebelakang tentang suatu kejadian yang berhubungan dengan kejadian kesakitan yang diteliti saat ini. Penilitaan ini dilakukan di kecamatan kutambaru dengan melihat determinan / faktor risiko terjadinya malaria Dengan tingkat kepercayan $95 \%$ dan $a=5 \%$, hasil $P<0,05$.

Hasil analisis data diperoleh faktor risiko kebersihan terhadap kejadian Malaria $\mathrm{p}=0,003$, Odds Ratio $=3,852$ dengan Confidence Interval $(\mathrm{CI})=1,574-9,428$. Temperatur $\mathrm{p}=0,025$, Odds Ratio $=2,833$, Genangan air $\mathrm{p}=0,011$ dan Odds Ratio= 3,063 , Penggunaan Kelambu $p=0,350(p>0,05)$, Pengunaan obat anti nyamuk $p=0,033$, Kebiasaan keluar rumah pada malam hari $p=0,055$, faktor Umur $p=0,392$ dan Odds Ratio $=1,444$, Jenis kelamin terhadap Malaria $p=0,831$ dan Odds Ratio $=1,095$. Pada penelitian ini variabel yang menjadi faktor risiko terjadinya malaria adalah kebersihan, temperatur, genangan air, kelambu, anti nyamuk, keluar rumah, umur dan jenis kelamin. Untuk mendapat faktor mana yang paling dominan dengan terjadinya Malaria maka variabel tersebut diuji secara bersama-sama dengan dilakukan uji regresi logistik berganda dengan menggunakan metode enter. Ada dua variabel yang memiliki $p<0,025$ yaitu kebersihan dan genangan air, sehingga diperoleh masing-masing odds ratio 4,402 dan 3,562. Saran untuk penelitian ini berguna bagi Dinas kesehatan, Institusi dan peneliti.
\end{abstract}

\section{Kata Kunci : Malaria, Determinan, Odds ratio}

\section{Pendahuluan}

Penyakit malaria sudah diketahu sejak zaman yunani, Malaria merupakan salah satu penyakit menular yang masih sangat menjadi masalah bagi kesehatan masyarakat dunia yang menyebabkan kematian terutama pada kelompok resiko tinggi yaitu bayi, anak balita, ibu hamil, selain itu malaria menyebabkan anemia dan dapat menurunkan produktifitas kerja.

Malaria salah satu penyakit parasit yang tersebar luas di seluruh dunia meskipun umumnya terdapat di daerah berlokasi antara $60^{\circ}$ Lintang Utara dan $40^{\circ}$ Lintang Selatan. Malaria hampir ditemukan diseluruh bagian dunia, terutama di negara-negara yang beriklim tropis dan sub tropis dan penduduk yang berisiko terkena malaria berjumlah sekitar 2,3 milyar orang atau $41 \%$ dari jumlah penduduk dunia. Setiap tahun kasusnya berjumlah 300-500 juta kasus dan mengakibatkan 1,5 - 2,7 juta kematian, terutama dinegara-negara benua Afrika (Arsin.,AA. 2012).

Berdasarkan data dari World Health Organization (WHO), pada tahun 2008 terdapat sekitar 243 juta kasus malaria seluruh dunia, estimasi kematian yang diakibatkan oleh penyakit malaria pada tahun 2010 adalah 655.000 kasus malaria di seluruh dunia. Selain itu, tercatat $86 \%$ kematian terjadi pada anak di bawah umur 5 tahun. Penderita penyakit ini tersebar di daerah di seluruh dunia terutama di daerah endemis seperti Afrika dan Asia (WHO, 2013). 
Malaria masih merupakan salah satu masalah kesehatan masyarakat yang utama, karena mempengaruhi angka kesakitan bayi, balita, dan ibu melahirkan, serta menimbulkan kejadian luar biasa (Harijanto PN, 2012). Malaria merupakan penyakit menular yang menjadi masalah kesehatan masyarakat di Indonesia, karena menimbulkan angka kesakitan dan kematian yang tinggi serta menurunkan produktivitas sumber daya manusia dan pembangunan nasional (Kemenkes RI (2013).

Malaria pada penduduk Indonesia tahun 2013 adalah turun 1,9\% dibanding tahun 2007 (2,9\%), tetapi di Papua Barat mengalami peningkatan tajam jumlah penderita malaria. Prevalensi malaria tahun 2013 adalah 6,0\%. Lima provinsi dengan insiden dan prevalensi tertinggi adalah Papua $(9,8 \%$ dan $28,6 \%)$, Nusa Tenggara Timur $(6,8 \%$ dan $23,3 \%)$, Papua Barat $(6,7 \%$ dan $19,4 \%)$, Sulawesi Tengah $(5,1 \%)$ dan $12,5 \%)$, dan Maluku (3,8\% dan $10,7 \%$ ). Dari 33 provinsi di Indonesia, 15 provinsi mempunyai prevalensi malaria di atas angka nasional, sebagian besar berada di Indonesia Timur, hal ini disebabkan karena adanya keterbatasan sumber daya pemerintah dalam masalah tenaga dan dana serta tingginya perbedaan endemisitas antar daerah juga dianggap menjadi tantangan penanggulangan malaria. Provinsi di Jawa-Bali merupakan daerah dengan prevalensi malaria lebih rendah dibanding provinsi lain (Riskesdas., 2013).

Malaria adalah penyakit infeksi akut maupun kronis yang disebabkan oleh plasmodium malaria dengan demam yang rekuren, anemia dan hepatosplenomegali. Malaria adalah penyakit infeksi yang disebabkan oleh parasit plasmodium yang hidup dan berkembang biak dalam sel darah merah manusia. Penyakit ini secara alami ditularkan melalui gigitan nyamuk anopheles betina.

Munculnya penyakit malaria disebabkan oleh berbagai faktor yang menunjang vektor nyamuk anopheles bisa tetap survival karena penyesuaian terhadap lingkungan yang ada sehingga faktor yang pertama adalah Lingkungan, kemudian perilaku, pelayanan kesehatan dan hereditas. Hal ini serupa yang diungkapkan oleh Blum (1974) bahwa faktor yang mempengaruhi derajat kesehatan masyarakat adalah: Lingkungan, Perilaku, Pelayanan Kesehatan, dan Hereditas (Arsin.,AA. 2012).

Lingkungan adalah segala sesuatu yang ada di sekitar manusia, baik berupa benda hidup, benda mati, benda nyata ataupun abstrak, termasuk manusia lainnya, termasuk suasana yang terbentuk, maka terjadi interaksi di antara elemen - elemen di alam tersebut. Faktor lingkungan menempati urutan ke3 dalam indikator kunci status kesehatan masyarakat. Ketinggian, kelembaban, curah hujan, kondisi satwa maupun tumbuhan memainkan peranan di sini. Tetapi bagaimanapun juga, kondisi lingkungan dapat dimodifikasi dan dapat diperkirakan dampak atau ekses buruknya sehingga dapat di carikan solusi ataupun kondisi yang paling optimal bagi kesehatan manusia (Arsin.,AA. 2012).

$\begin{array}{llr}\text { Sumatera utara merupakan } \\ \text { daerah yang endemis } & \text { malaria } \\ \text { diantaranya kabupaten } & \text { langkat, } \\ \text { deliserdang, labuhan batu, serdang }\end{array}$ bedagai, asahan, samosir, tapanuli tengah, tapanuli utara, tapanuli selatan, mandailing natal, nias, nias selatan, batubara, padang lawas, padang lawas utara dan kabupaten labuhan batu utara (Dinkes Sumut., 2012).

Survei pendahuluan yang telah dilakukan kecamatan Kutambaru adalah salah satu daerah endemis penyakit malaria, tercatat sebanyak 63 orang ditemukan kasus penyakit malaria di wilayah kerja puskesmas kecamatan kutambaru . Kecamatan Kutambaru merupakan daerah yang berada di daerah dataran tinggi dan berbatasan langsung dengan kawasan bukit barisan (Profil Puskesmas Kutambaru tahun 2015).

Berdasarkan uraian diatas penulis sangat tertarik dan mendorong peneliti di daerah langkat khususnya kecamatan kutambaru untuk meneliti dan membuat suatau penelitian dengan judul Analiss Determinan Kejadian Malaria Kecamatan Kutambaru Tahun 2017.

Bertolak dari uraian yang telah dikemukakan pada latar belakang maka permasalahan dapat di rumuskan bagaimanakah faktor-faktor risiko mempenggaruhi kejadian Malaria di kecamatan Kutambaru tahun 2017. 
Tujuan penelitian ini adalahMenganalisis faktor-faktor risiko pada kejadian malaria di kecamatan Kutambaru tahun 2017.

\section{Metode Penelitian}

Dalam

penelitian

akan

menggunakan penelitian analitik dengan desain case control, yaitu suatu penelitian dengan membandingkan kelompok kasus dengan kelompok kontrol untuk mengetahui proporsi kejadian berdasarkan riwayat ada tidaknya paparan.Memilih dua kelompok berdasarkan status kesehatan/penyakit, dimana kelompok penyakit (kasus) dan kelompok tanpa penyakit (kontrol).

Penelitian ini bersifat retrospektif yaitu rancang bangun dengan melihat kebelakang tentang suatu kejadian yang berhubungan dengan kejadian kesakitan yang diteliti saat ini. Penelitian ini berupaya untuk melihat faktor penyebab dimasa lalu terhadap kejadian sekarang. Penelitian ini diawali dari variabel dependen dengan subjek penelitian yang telah dikelompokkan menjadi dua yakni kelompok kasus dan kelompok kontrol.

Desain ini dipilih dengan pertimbangan bahwa dibandingkan dengan desain studi analitik lainnya, biaya studi kasus kontrol lebih murah dan secara teknis lebih mudah dilakukan. Kekuatan hubungan sebab akibat rancangan studi kasus kontrol lebih kuat dibandingkan dengan studi belah melintang. Studi kasus kontrol membutuhkan jumlah sampel yang lebih kecil dibandingkan studi kohort dan membutuhkan waktu lebih singkat. Dibandingkan dengan studi eksperimental, studi kasus kontrol secara etika lebih memungkinkan untuk dilakukan.

Sampel penelitian ini akan dilaksanakan di kecamatan Kutambaru, kabupaten Langkat, Sumatera Utara. Waktu penelitian dilaksanakan pada bulan Maret s/d Mei 2017. Populasi adalah keseluruhan objek penelitian atau objek yang diteliti. Populasi dalam penelitian ini adalah seluruh pasien yang di diagnosa malaria di puskesmas kecamatan kutambaru. Populasi dalam penelitian ini adalah sebanyak 63 orang.

Sampel adalah objek yang diteliti dan dianggap mewakili seluruh populasi.
Untuk mengetahui besar sampel dalam penelitian ini diambil dengan menggunakan rumus Bhisma M, 2010

Besarnya sampel penelitian dengan memperhatikan Odds Ratio hasil dari beberapa penelitian terdahulu tentang beberapa faktor risiko kejadian malaria sebesar 4,461 (Mido S, 2013). Dengan menggunakan ketentuan proporsi keterpaparan faktor penderita Malaria sebesar 30\% (Mido S, 2013). Dari rumus diatas didapatkan jumlah sampel sebanyak 44 orang, maka untuk sampel pada penelitian ini sebanyak 44 orang sebagai sampel kasus dan 44 orang sebagai sampel kontrol.

Sebelum dilakukan pengambilan sampel maka terlebih dahulu dilakukan kreteria inklusi dan eksklusi. Teknik pengambilan sampel yaitu dengan metode purposive sampling.

Data primer adalah data yang didapat atau dikumpul oleh peneliti dengan cara langsung waktu saat penelitian. Data sekunder dalam penelitian ini adalah data yang di dapat dari dinas terkait, seperti dinas kesehatan, kantor kecamatan dan sebagainya.

\section{Analisis Univariat}

Analisis data secara univariat dilakukan untuk mendapatkan gambaran distribusi frekuensi responden. Analisis ini digunakan untuk memperoleh gambaran pada masing-masing variabel bebas dan variabel terikat.

\section{Analisis Bivariat}

Analisis bivariat dilakukan untuk menguji seluruh variable. Metode statistik yang di gunakan adalah uji Chi-square. Analisis bivariat dilakukan untuk menguji faktor-faktor resiko pada penderita malariamenggunakan uji chi square. Dasar pengambilan keputusan penerimaan hipotesis penelitian berdasarkan tingkat signifikansi (nilai $p$ ).

Selanjutnya juga mengetahui besar risiko (Odds Ratio/OR) paparan terhadap kasus dengan menggunakan tabel 2X2. Nilai besarnya Odds Ratio ditentukan dengan rumus $\mathrm{OR}=$ a.d / b.c atau mantel-haenszel dengan Confidence Interval (CI) 95\%. 


\section{Analisis Multivariat}

Analisis multivariat dengan menggunakan uji regresif logistik. Analisis ini dilakukan dengan cara menganalisis beberapa variabel bebas dengan variable terikat dengan metode enter dan dimasukkan secara bersamaan. Analisis multivariat untuk mendapat model yang terbaik, Semua variabel kandidat dimasukkan bersama-sama untuk dipertimbangkan menjadi model dengan nilai signifikan $p<0,05$. Variabel terpilih dimasukkan dalam model dan nilai $p$ yang tidak signifikan dikeluarkan berurutan dari nilai $p$ tertinggi.

\section{Hasil Penelitian}

Penelitian ini telah dilakukan di kecamatan kutambaru. Kutambaru adalah kecamatan yang merupakan pemekaran dari induk Kecamatan Salapian yang merupakan bagian dari Kabupaten Langkat Provinsi sumatera Utara, yang terdiri 8 Desa yang berada diantara wilayah Perkebunan PTPN II Maryke dan Perkebunan London Sumatera. Kontur alam yang berada di perbatasan dengan Taman Nasional Gunung Leuser yang berbatasan dengan Kecamatan Bahorok dan Dataran Tinggi tanah Karo. Kecamatan Kutambaru dengan Luas 244,09 Km2 Dengan Jumlah Penduduk 15.432 Jiwa dengan Jumlah KK 4534 Terdiri Dari 8 Desa dan 1 Desa Perkebunan.

\section{Analisis Univariat}

Analisis univariat berguna untuk melihat karakteristik responden kasus dan kontrol. Responden kasus adalah penderita malaria sedangkan kontrol adalah yang tidak malaria, dimana karakteristik responden menurut kebersihan yang tidak bersih sebanyak 26 orang $(59,1 \%)$ menderita malaria dan 12 orang $(13,3 \%)$ yang tidak malaria. Responden yang bersih sebanyak 18 orang $(40,9 \%)$ malaria dan 32 orang $(86,7 \%)$ yang tidak malaria.

Karakteristik responden menurut temperatur adalah tempratur rendah dan tinggi. Dari temperatur rendah sebanyak 34 responden $(77,3 \%)$ yang menderita malaria dan yang tidak malaria sebanyak 24 responden $(54,5 \%)$, sedangkan temperatur tinggi sebanyak 10 responden
$(22,7 \%)$ yang malaria dan sebanyak 20 responden $(45,5 \%)$ yang tidak malaria.

Responden yang memiliki genangan air disekitar rumahn 28 responden $(63,63 \%)$ yang malaria dan yang tidak malaria sebanyak 16 responden $(36,4 \%)$, sedangkan yang memiliki tidak memiliki genangan air sebanyak 16 responden $(36,4 \%)$ yang Malaria dan sebanyak 28 responden yang tidak Malaria.

Responden menurut penggunaan kelambu yang tidak memakai kelambu saat tidur sebanyak 33 responden $(75,0 \%)$ yang malaria dan 29 responden $(30,0 \%)$ yang tidak malaria, sedangkan yang memakai kelambu sebanyak 11 responden $(25 \%)$ yang malaria dan 15 responden $(20 \%)$ yang tidak malaria.

Responden yang menggunakan obat anti nyamuk di rumah, yang tidak memakai obat anti nyamuk di rumah sebanyak 17 responden $(36,6 \%)$ yang malaria dan 27 responden $(30,0 \%)$ yang tidak malaria, sedangkan yang memakai obat anti nyamuk sebanyak 27 responden $(63,4 \%)$ yang malaria dan 17 responden $(36,6 \%)$ yang tidak malaria.

Sedangkan menurut kebiasaan keluar rumah, responden yang memiliki kebiasaan keluar rumahsaat malam hari yaitu sebanyak 26 responden $(59,1 \%)$ yang Malaria dan 17 responden $(38,6 \%)$ tidak malaria, yang tidak memiliki kebiasaan keluar rumah malam hari 18 responden $40,9 \%$ ) yang malaria dan 27 responden $(61,4 \%)$ tidak malaria.

Dilihat dari umur responden dengan usia < 20 tahun 26 orang $(59,1 \%)$ yang menderita malaria dan 22 orang $(50,0 \%)$ yang tidak malaria, Sedangkan untuk usia $\geq 20$ tahun 18 orang yang menderita malaria dan 22 orang yang tidak menderita malaria.

Dari jenis kelamin laki-laki yang menderita malaria sebanyak 23 responden $(52,3 \%)$ dan yang tidak malaria sebanyak 22 responden $(50,0 \%)$, sedangkan jenis kelamin perempuan sebanyak 21 responden $(47,7 \%)$ yang malaria dan sebanyak 22 responden yang tidak malaria.

Suku sudah disesuaikan antara kasus dan kontrol. Responden terbanyak menderita malaria adalah suku karo yaitu sebanyak 36 responden $(81,8 \%)$ yang terkecil adalah suku jawa yaitu sebanyak 8 responden $(18,2 \%)$. 
Bagian tempat bekerja juga sudah disesuaikan antara kasus dan kontrol. Untuk jenis pekerjaan, responden terbanyak yaitu masing-masing sebanyak 20 responden (45,5\%) adalah petani. Jumlah responden terkecil adalah wiraswasta masing-masing 4 responden $(9,1 \%)$.

\section{Analisis Bivariat}

Analisis bivariat akan menjelakan pengaruh antara faktor risiko / determinan terhadap kejadian malaria. Faktor risiko kebersihan terhadap kejadian malaria didapati pengaruh yang signifikan antara yang menjaga kebersihan dan yang tidak menjaga kebersihan terhadap terjadinya Malaria $p=0,003 \quad(p<0,05) \quad$ dan selanjutnya diperoleh Odds Ratio $=3,852$ dengan Confidence Interval $(\mathrm{CI})=1,574-9,428$. Dengan kata lain peluang terjadinya Malaria 3,852 kali lebih besar pada responden yang tidak menjaga kebersihan dibandingkan dengan responden yang menjaga kebersihan di wilayah kerja puskemas kecamatan kutambaru.

Determinan temperatur terhadap kejadian malaria di kecamatan kutambaru didapati pengaruh yang signifikan antara temperatur yang rendah dan temperatur tinggi terhadap kejadian malaria $p=0,025 \quad(p<0,05)$ dan selanjutnya diperoleh Odds Ratio $=2,833$ dengan Confidence Interval $(\mathrm{CI})=1,127$ 7,121 . Dengan kata lain peluang terjadinya Malaria 2,833 kali lebih besar pada temperatur rendah daripada temperatur tinggi di wilayah kerja puskemas kecamatan kutambaru.

Faktor risiko genangan air terhadap kejadian malaria didapati pengaruh yang signifikan antara rumah yang memiliki genangan air yang tidak di tutup terhadap terjadinya penyakit malaria $p=0,011 \quad(p<0,05)$ dan selanjutnya diperoleh Odds Ratio $=3,063$ dengan Confidence Interval $(\mathrm{CI})=1,285$ 7,300. Dengan kata lain peluang terjadinya Malaria 3,063 kali lebih besar pada responden yang memiliki genangan air di rumah dibanding responden yang tidak memiliki genangan air di rumah.

Faktor penggunaan kelambu didapati tidak ada pengaruh yang signifikan terhadap kejadian malaria antara responden yang menggunakan kelambu dan responden yang tidak menggunakan kelambu $p=0,350$ $(p>0,05)$ di wilayah kerja puskemas kecamatan kutambaru.

Pengunaan obat anti nyamuk berpengaruh terhadap kejadian malaria, didapati pengaruh yang signifikan antara yang responden yang menggunakan obat anti nyamuk dan yang tidak menggunakan obat anti nyamuk terhadap terjadinya Malaria $p=0,033(p<0,05)$.

Faktor kebiasaan keluar rumah pada malam hari didapati tidak ada pengaruh yang signifikan antara faktor kebiasaan keluar rumah malam hari dan yang tidak memiliki kebiasaan keluar rumah pada malam hari terhadap terjadinya Malaria $p=0,055(p>0,05)$.

Analisis faktor umur terhadap kejadian malaria tidak terdapat pengaruh yang signifikan antara umur muda $(<20$ th) dan umur dewasa ( $\geq 20$ th) terhadap terjadinya Malaria $p=0,392(p>0,05)$ dan selanjutnya diperoleh Odds Ratio $=1,444$ dengan Confidence Interval $(\mathrm{CI})=0,622-$ 3,355 .

Sedangkan Analisis faktor risiko jenis kelamin terhadap kejadian malaria juga tidak terdapat pengaruh yang signifikan antara jenis kelamin laki-laki dan perempuan terhadap terjadinya Malaria $p=0,831 \quad(p>0,05)$ dan selanjutnya diperoleh Odds Ratio $=1,095$ dengan Confidence Interval $(\mathrm{CI})=0,475$ 2,527 .

\section{Analisis Multivariat}

Pada penelitian ini variabel yang menjadi faktor resiko terjadinya malaria adalah kebersihan, temperatur, genangan air, kelambu, anti nyamuk, keluar rumah, umur dan jenis kelamin . Untuk mendapat faktor mana yang paling dominan dengan terjadianya hipertensi maka kedua variabel tersebut diuji secara bersama-sama dengan dilakukan uji regresi logistik berganda dengan menggunakan metode enter. Ada dua variabel yang memiliki $p<0,025$ yaitu kebersihan dan genangan air maka layak untuk dimasukkan.

Dari tabel dibawah menunjukkan bahwa kebersihan lingkungan memiliki faktor resiko yang paling dominan dengan nilai exponen (B) 4,402. Seperti terlihat pada tabel dibawah: 
Tabel. Regresi Logistik Berganda Antara faktor Kebersihan dan genangan air terhadap Kejadian Malaria

\begin{tabular}{llll}
\hline Variabel & $\begin{array}{l}\text { Koefisie } \\
\text { n B }\end{array}$ & $\begin{array}{l}\text { Exponen } \\
\text { (B)/Odd } \\
\text { s Ratio }\end{array}$ & P \\
\hline Kebersiha & 1.482 & 4,402 & 0.00 \\
n & & 3,562 & 0.00 \\
Genangan & 1.270 & 8 \\
air & & & \\
Constant & $-4,236$ & 0,014 & 0.00 \\
& & & 0 \\
\hline
\end{tabular}

\section{Pembahasan Hasil}

\section{Kejadian Malaria}

Kejadian malaria sudah ada sejak dulu di kecamatan kutambaru, yang dulu masih sebagai desa kutambaru bagian dari kecamatan salapian. Kecamatan kutambaru merupakan daerah endemis malaria hal ini sesuai dari laporan penemuan dan pengomatan puskesmas kecamatan kutambaru. Adapun bebrapa desa yang menjadi daerah endemis malaria pada tahun 2017 adalah desa Namoteras, desa Rampah, desa Sulkam, dan desa Kaperas. Hal ini sejalan dengan penelitian Mido Ester J Sitorus yang berjudul faktor-faktor yang mempengaruhi kejadian malaria di wilayah kerja puskesmas marike kecamatan kutambaru kabupaten langkat tahun 2013

\section{Kebersihan}

Sesuai dengan table 4.1 univariat dan table 4.11 bivariat menunjukkan bahwa faktor kebersihan memiliki pengaruh yang signifikan, hal ini sejalan dengan banyak penelitian diantaranya penelitian Junus Widjaja dengan judul Determinan kejadian malaria di wilayah Sulawesi tahun 2016, juga penilitian Mido Ester J Sitorus tahun 2013 di kecamatan kutambaru sendiri. Kebersihan dan genangan air karena memiliki $\mathrm{P}<0,025$ maka dimasukkan ke dalam analisis multivariat dan hasilnya kebersihan berpengaruh 4,402 kali terhadap kejadian malaria di kecamatan kutambaru. Hal ini kemungkinan disebabkan karena kebanyakan hidup bertani sehingga kurang menjaga kebersihan dan faktor minimnya pengetahuan serta informasi yang menyebabkan kurang terjaganya kebersihan di lingkungan tempat tinggal, dan dari penelitian ini juga didapat banyak penduduk belum meliki kamar mandi yang layak.

\section{Temperatur}

Temperatur rendah berpengaruh terhadap kejadian malaria, artinya cuaca yng dingin dapat menyebabkan malaria, dimana didapati pengaruh yang signifikan antara temperatur yang rendah dan temperatur tinggi terhadap kejadian malaria $p=0,025 \quad(p<0,05) \quad$ dan selanjutnya diperoleh Odds Ratio $=2,833$ dengan Confidence Interval $(\mathrm{CI})=1,127-$ 7,121 . Hal ini sejalan dengan penelitian Husen hasan di provinsi Bengkulu tahun 2007 namun bertolak belakang dengan penelitian yang dilakukan Irma rubianti yang menilai faktor-faktor risiko malaria di wilayah kerja puskesmas paruga kota Bima Nusa Tenggara barat.

\section{Genangan air}

Genangan air merupan faktor risiko yang berpengaruh sangat signifikan. Faktor risiko genangan air terhadap kejadian malaria didapati pengaruh yang signifikan antara rumah yang memiliki genangan air yang tidak di tutup terhadap terjadinya penyakit malaria $p=0,011 \quad(p<0,05)$ dan selanjutnya diperoleh Odds Ratio $=3,063$ dengan Confidence Interval $(\mathrm{CI})=1,285-7,300$. Dengan kata lain peluang terjadinya Malaria 3,063 kali lebih besar pada responden yang memiliki genangan air di rumah dibanding responden yang tidak memiliki genangan air di rumah. Hal ini sejalan dengan penelitian Mido ester tahun 2013, Kholis Ernawati tahun 2010 di lampung, dan Babba Ikramaya di Jayapura namun bertolak belakang dengan penelitian Irma rubianti di kota Bima Nusa Tenggara Barat. Genangan air karena memiliki $\mathrm{P}<0,025$ maka dimasukkan ke dalam analisis multivariat dan hasilnya genangan air berpengaruh 3,562 kali terhadap kejadian malaria di kecamatan kutambaru. Hal ini kemungkinan disebabkan rata-rata penduduk hidup dari bertani karet dan sekaligus tempat tinggal mereka. Hasil karet ditampung dalam bak atau wadah 
yang berada tidak jauh sekitar rumah, dan penduduk juga masih menggunanakan air tadah hujan sebagai mandi, cuci, dan kakus (MCK).

\section{Penggunaan Kelambu}

Penggunaan kelambu dalam penelitian ini tidak berpengaruh signifikan didapati tidak ada pengaruh yang signifikan terhadap kejadian malaria antara responden yang menggunakan kelambu dan responden yang tidak menggunakan kelambu $p=0,350$ $(p>0,05)$ di wilayah kerja puskemas kecamatan kutambaru. Hal ini sejalan dengan penelitian Irma Rubianti di Nusa Tenggara Barat dan bertolak belakang dengan penelitian Husen Hasan tahun 2007 yang menyatakan ada pengaruh penggunaan kelambu dengan kejadian Malaria.

\section{Penggunaan Obat Anti Nyamuk}

Pengunaan obat anti nyamuk berpengaruh terhadap kejadian malaria, didapati pengaruh yang signifikan antara yang responden yang menggunakan obat anti nyamuk dan yang tidak menggunakan obat anti nyamuk terhadap terjadinya Malaria $p=0,033(p<0,05)$. Hal ini sejalan dengan penelitian Junus Widjaja tahun 2016, Hasan Husen tahun 2007, dan Irma Rubianti di Bima NTB. Namun bertolak belakang dengan penelitian Ernawati Kholis di provinsi lampung.

\section{Kebiasaan Keluar Rumah}

Dalam penelitian ini Faktor kebiasaan keluar rumah pada malam hari didapati tidak ada pengaruh yang signifikan antara faktor kebiasaan keluar rumah malam hari dan yang tidak memiliki kebiasaan keluar rumah pada malam hari terhadap terjadinya Malaria $p=0,055 \quad(p>0,05)$. Hal ini sejalan dengan penelitian Kholis ernnawati tahun 2010 namun bertolak belakang dengan penelitian Junus Widjaja tahun 2016 dan Irma Rubianti di Nusa Tenggara barat.

\section{Umur}

Analisis faktor umur terhadap kejadian malaria tidak terdapat pengaruh yang signifikan antara umur muda $(<20$ th) dan umur dewasa ( $\geq 20$ th) terhadap terjadinya Malaria $p=0,392(p>0,05)$ dan selanjutnya diperoleh Odds Ratio $=1,444$ dengan Confidence Interval $(\mathrm{CI})=0,622$ 3,355 . Hal ini sejalan dengan penelitian Babba Ikramaya tahun 2006 di kota jayapura namun bertolak belakang dengan penelitian Hasan Husen di kota Bengkulu tahun 2007

\section{Jenis Kelamin}

Analisis faktor risiko jenis kelamin terhadap kejadian malaria juga tidak terdapat pengaruh yang signifikan antara jenis kelamin laki-laki dan perempuan terhadap terjadinya Malaria $p=0,831$ $(p>0,05)$ dan selanjutnya diperoleh Odds Ratio $=1,095$ dengan Confidence Interval $(C I)=0,475-2,527$. Hal ini sejalan dengan penelitian hasan husein yang menyatakan tidak ada pengaruh antara jenis kelamin terhadap terjadinya penyakit malaria namun nbertolak belakang dengan penelitian Babba Ikramaya tahun 2006 yang menyatakan ada pengaruh jenis kelamin dengan kejadian malaria.

\section{KESIMPULAN}

Dari Penelitian ini dapat diambil kesimpulan bahwa faktor kebersihan, temperatur, genangan air, penggunaan obat anti nyamuk berpengaruh terhadap Malaria, sedangakan faktor penggunaan kelambu, kebiasaan keluar rumah malam hari, umur dan jenis kelamin tidak berpengaruh terhadap kejadian malaria. Faktor kebersihan dan genangan air dinilai memiliki faktor yang paling berpengaruh terhadap kejadian malaria.

Faktor kebersihan diperoleh nilai odds ratio $(\mathrm{OR})=4,402$ artinya individu/masyarakat yang tidak bersih/ kurang menjaga kebersihan lingkungannya memiliki resiko 4,402 kali lebih besar untuk terjadinya malaria di kecamatan Kutambaru.

Genangan air merupakan faktor risiko, penduduk yang memiliki genangan air radius \pm 500 meter dari rumahnya memiliki risiko terjadinya malaria. Dari genangan air diperoleh nilai odds ratio $(\mathrm{OR})=3,562$, artinya penduduk yang memiliki genangan air di lingkungan rumah memiliki risiko 3,562 kali lebih besar untuk terjadinya malaria.

\section{Saran}

Dinas kesehatan yang dalam hal ini di mulai dari puskesamas kecamatan 
kutambaru dan dinas kesehatan kabupaten langkat agar lebih memonitoring dan menjalankan surveilance guna menekan angka kejadian malaria yang tiap tahun belum tampak perubahan dari angka kejadian malaria tiap tahunnya. Kebersihan dan genangan air merupakan faktor risiko yang paling berpengaruh terhadap kejadian malaria, sehingga bagian yang terkait diharapkan dapat lebih mengoptimalkan kinerjanya, dan penilitan ini menjadi masukan yang berharga nantinya.

Bagi institusi karena ini penelitian dosen yang pertama dari Fakultas Kedokteran Universitas Islam Sumatera Utara maka diharapakan penelitian semakin berkembang, dan dosen-dosen lebih giat melakukuan penilitian yang merupakan bagian dari tri dharma perguruan tinggi. Kecamatan kutambaru merupakan daerah terpencil dan masih jarang dilakukan penelitian sehingga nantinya diharapkan bisa menjadi daerah binaan untuk mencapai tujuan penelitian, dakwah dan pengabdian masyarakat.

Bagi peneliti ini merupakan awal bagi kita untuk menggembangkan penelitian diranah keilmuan masingmasing dan bisa menggembangkan penelitian di lintas sektor, artinya dengan disiplin ilmu yang berbeda.

\section{DAFTAR PUSTAKA}

Arsin.,AA. 2012. Malaria di Indonesia tinjauan aspek epidemiologi Makasar : Masagena Press

Arsin., AA. 2008. Pola spasial kasus malaria dengan aplikasi Sistem Informasi Geografis (SIG) di kabupaten Halmahera tengah, Makasar: FKM UNHAS

Arwati H, Kusmartisnawati, Poppy $H$, Dachlan YP. 2013. Asymptomatic Malaria in Trenggalek District, East Java Province As Revealed By Microscopic Examination and Single Step PCR. Folia Media Indonesiana 3 : 150-154.

Babba I., 2006. Faktor risiko yang mempengaruhi kejadian malaria (studi kasus di wilayah kerja puskesmas hanadi kota jayapura,
Semarang : Magister Epidemiologi UNDIP

Castellanos ME, Díaz S, E, Peruski LF et al. 2015.First imported Plasmodium ovale malaria in Central America: case report of a Guatemalansoldier and a call to improve its accuratediagnosis, Military Medical Research 2015 2:3.

Collins WE, Jeffery GM. 2005. Plasmodium ovale: Parasite and Disease, ClinicaL Microbiology Reviews, American Society for Microbiology 18 : 3 , July $2005,570-81$

Dinkes Sumut., 2012. Profil Kesehatan Provinsi Sumatera Utara Tahun 2012. Medan, Diunduh dari:www.depkes.go.id/resources/dow nload/profil/PROFIL KES PROVINSI 2 012/02 Profil_Kes Prov.SumateraUta ra 2012.pdf pada tanggal 8 Juni 2015.

Ernawati K., 2011. Hubungan faktor risiko individu dan lingkungan rumah dengan malaria di punduh pedada kabupaten pesawaran provinsi lampung, Jakarta: Pascasarjana UI

Gray KA, Dowd S, Brain L, Bobogare A, Winni L, Shanks GD, Cheng Q 2013). Population genetics of Plasmodium falciparum dan Plasmodium vivax and asymptomatic malaria in Temotu Province, Solomon Island. Malaria Journal 12, 429.

Harijanto, PN., 2012. Gejala Klinis Malaria Ringan. Dalam: Harijanto PN, Nugroho A, Gunawan CA. (Ed). Malaria Dari Molekuler ke Klinis. EGC: Jakarta, 86-7.

Harijanto, PN., 2014. Malaria. Dalam : Buku Ajar Ilmu Penyakit Dalam Edisi VI. Setiati T, Alwi I, Suroyo A.W, K. Marcellus S, Syam A.S (Editor) Interna Publisher. Jakarta : 595-612.

Husin hasan., 2007. Analisis faktor risiko kejadian malaria di puskesmas suka merindu kecamatan sungai serut kota Bengkul, Bengkulu

Kemenkes RI, 2013. Pedoman Tata Laksana Malaria SK Menkes RI Nomor 5 Tahun 2013. Jakarta.

Laishram DD, Sutton PL, Nanda N, Sharma VL, Sobti RC, Carlton JM, Joshi $\mathrm{H}$, 2012. The Complexities of malaria diseas manifestation with a focus on asymptomatic malaria. Malaria Journal 11,29. 
Notoadmojo.,S., 2013. Metode penelitian kesehatan.Jakarta:Rineka Cipta

Riskesdas., 2013. Riset Kesehatann Dasar. Departemen Kesehatan RI: Badan Penelitian dan Pengembangan Kesehatan.

Rubianti I., 2009. faktor-faktor risiko malaria di wilayah kerja puskesmas paruga kota bima nusa tenggara barat, Yogyakarta :FKM Univ. Ahamd dahlan

Sitorus., MEJ., 2013. Faktor- faktor yang mempengaruri kejadian Malaria di wilayah kerja puskesmas marike, Langkat.

Sororntou, Y. , 2013. Imunologi Parasit Malaria. Dalam Ilmu Malaria Klinik. EGC: Jakarta. Hal : 88-90.

Sutanto I, Ismid IS, Sjarifuddin PK, SungkarS, 2008. Buku Ajar Parasitologi Kedokteran. Ed 4. Jakarta : EGC.

WHO, 2013. World Malaria Report 2013. Geneva : World Health Organization. Available from http://www.who.int/mediacentre/new s/releases/2013/world-malaria-report 20131211/en/index.htm. Accessed August 20, 2015.

WHO, 2014. World Malaria Report 2014 Geneva : World Health Organization. Available from http://www.who.int/mediacentre/new s/releases/2013/world-malaria-report 20131211/en/index.htm. Accessed September 15, 2015.

Widjaja junus., 2016. Determinan kejadian malaria di wilayah sulawesi, Donggala: Bali litbang P2B2 